\title{
INFLUENCE OF THE MARINATING TYPE ON THE MORPHOLOGICAL AND SENSORY PROPERTIES OF HORSE MEAT
}

\author{
Dessislava B. Vlahova-Vangelova ${ }^{1 凶}$, Sholpan Abjanova ${ }^{2}$, Stefan G. Dragoev ${ }^{1}$ \\ ${ }^{1}$ Department Meat and Fish Technology, Technological Faculty, University of Food Technologies \\ 26 Maritza blvd 4002 Plovdiv, Bulgaria \\ ${ }^{2}$ Department of Food Technology, Faculty of Food Production, Almaty Technological University \\ 100 Tole bi str., Almaty, Kazakhstan
}

\begin{abstract}
Background. The aim of this study was to explore the influence of acid, alkaline and water-oil marinating on morphological changes and sensory properties of horse meat (m. Longissimus dorsi).

Material and methods. Nine samples $(\mathrm{C}$ - control stored in air, $\mathrm{AL}$ - alkaline marinated in $2 \%$ polyphosphates and $2 \%$ sodium chloride brine solution, $\mathrm{AC}$ - acid marinated in $2 \%$ sodium lactate and $2 \%$ sodium chloride brine solution, WO - marinated in water-oil emulsion (50/50) contained and $2 \%$ sodium chloride and $\mathrm{SC}$ - marinated in 2\% sodium chloride brine solution) were examined. After $24 \mathrm{~h}$ and $48 \mathrm{~h}$ of marinating changes in morphology of marinated meat, $\mathrm{pH}$ and sensory properties of raw and roasted samples were established.

Results. It was determined that sensory properties (aroma, flavor and tenderness) after roasting were classified as follows: AL48 > AL24 > AC24 > AC48 > SC48 > SC24 > WO24 > WO48 > C. Meat tenderness in AL48, AL24, AC24 and AC48 showed better results due to stronger morphological changes in connective and muscle tissues. Alkaline solutions were more suitable for horse meat marinating compared to acid solutions and the possible reason for strong action of alkaline solutions was lower internal meat $\mathrm{pH}$.

Conclusions. Alkaline marinating should be conducted for $24 \mathrm{~h}$ because after $48 \mathrm{~h}$ the meat acquires a soft and unusually tender texture. Water-oil marinating was not appropriate for horse meat.
\end{abstract}

Key words: horse meat, marinating, tenderness, morphology

\section{INTRODUCTION}

Marinating is a process in which meat is treated with different solutions for the purpose to enhance its appearance, to improve the quality, and to extend its shelf-life [Latif 2001]. On the other hand, marinade solutions enhance juiciness and tenderness of meat, and by increasing the quantity of added water they increase the yield of the finished product [Sheard and Tali 2004].

Depending on the type of ingredients used, marinade solutions are: alkaline (containing salt-phosphate mixtures), acid (containing organic acids or their salts) and water-oil emulsions. The typical example for alkaline marinade solutions are salt-phosphate mixtures added to fresh meat to improve their tenderness and juiciness [Brooks 2005]. Comparatively high $\mathrm{pH}$ during alkaline marinating increases water holding capacity due to protein extraction and shifting of the $\mathrm{pH}$ from the muscles proteins isoelectric point [Barbut 2002] and contributed to the dissociation of the actinmyosin complex. For the similar aim other authors use 
the so-called acidic marinades, which contain organic acids or their salts [Hinkle 2010].

Offer and Knight [1983] and Sultana et al. [2008] suggested that tenderness in acid marinated meat may be caused by changes in the connective tissue. According to Pearson and Young [1989] the irreversible changes occur at $\mathrm{pH}$ below 4.5 , after marinating with weak organic acids/their salts, causing decrease in functional activity and WHC.

Recently, most often marinades are offered constituting water-in-oil emulsions which contain a mix of salt, sugar, vinegar or citric acid and other additives [Björkroth 2005]. Besides the main ingredients, various types of marinade solutions may comprise fresh or dehydrated vegetables, ground spices and herbs or extracts thereof.

In the available literature references there are some studies on the influence of type of marinade solutions on the sensory and morphological characteristics of beef [Hinkle 2010], pork [Sheard and Tali 2004] and poultry [Alvarado and McKee 2007].

That is why the objective of the present study is to ascertain the influence of the marinade type on the sensory and morphological characteristics of horse meat.

\section{MATERIAL AND METHODS}

\section{Meat}

Horse $m$. Longissimus dorsi (age: 3 years, from one carcass, left side, 1 day post mortem) was purchased from Riton 38 Ltd village of Parvenets (Plovdiv district, Bulgaria). The meat was marinated for $24 \mathrm{~h}$ post mortem $\left(\right.$ at $0-4^{\circ} \mathrm{C}, \mathrm{pH}=6.0$ ).

\section{Marinade solutions}

Sodium lactate ( $60 \%$ solution) was purchased from Teokom Ltd (Sofia, Bulgaria). Polyphosphates were supplied from Fillab Ltd (Plovdiv, Bulgaria). Sodium chloride (salt), sugar and sunflower oil were delivered from the local market. One L $2 \%$ solution of sodium lactate was prepared by dilution of $60 \%$ sodium lactate, in which salt in concentration $2 \%$, was added.

The alkaline marinade solution was prepared by addition of $20 \mathrm{~g}$ polyphosphates and $20 \mathrm{~g}$ sodium chloride in $1 \mathrm{~L}$ water.

Twenty $g$ salt and five g sugar were added to $1 \mathrm{~L}$ water-oil emulsion, prepared from $500 \mathrm{~g}$ water and $500 \mathrm{~g}$ sunflower oil.

\section{Sample preparations}

After removing fats, ligaments and tendons from the muscle as much as possible, horse $m$. Longissimus dorsi was cut into total 25 parts with approximately same size (weight $40-50 \mathrm{~g}$; appr. $12 \times 8 \times 3 \mathrm{~cm}$ ) and randomly divided into five groups.

The samples were placed in four containers with marinade solution for $48 \mathrm{~h}$ and stored at $0-4^{\circ} \mathrm{C}$ (solution-sample ratio $=2: 1$ ). The control sample was stored in air conditions at $0-4^{\circ} \mathrm{C}$.

Nine samples were studied in this experiment, namely: control samples $\mathrm{C}$ - stored $19 \mathrm{~d}$ at $0-4^{\circ} \mathrm{C}$ in air; samples AL24 and AL48 - marinated for $24 \mathrm{~h}$ and $48 \mathrm{~h}$ in alkaline solution containing $2 \%$ polyphosphates and $2 \%$ sodium chloride; samples AC24 and AC48 - marinated for $24 \mathrm{~h}$ and $48 \mathrm{~h}$ in acid solution containing $2 \%$ sodium lactate and $2 \%$ sodium chloride; samples WO24 and WO48 marinated for $24 \mathrm{~h}$ and $48 \mathrm{~h}$ in water-oil emulsion (50/50) containing $2 \%$ sodium chloride and samples SC24 and SC48 - $24 \mathrm{~h}$ and $48 \mathrm{~h}$ salted in a brine containing only $2 \%$ sodium chloride.

The meat cuts were removed from the marinade solutions after $24 \mathrm{~h}(48 \mathrm{~h})$ soaking resp. The samples were placed separately in polymer thermal bags and were roasted in a conventional oven at $180^{\circ} \mathrm{C}$ until the temperature in the center of the meat reached $80^{\circ} \mathrm{C}$. The bags with cooked meat samples were cooled to room temperature and tested immediately [Ergezer and Gokce 2011].

Raw meat samples treated with or without marinade solution were observed under light optical microscope (Olimpus BX41TF, Japan) at magnification 1000x.

For the morphological analysis, meat cuts with size $2 \times 1 \times 1 \mathrm{~cm}$ from sample center were used. For light microscopic observation, the samples were cut into thin sections of approximately $5 \mu \mathrm{m}$. The fixation and contrasting of the samples with hematoxylin - eosin was done according to the methods described by Sultana et al. [2008].

Morphological observations were done in triplicate for each of the sample and the best representative picture was selected for this article.

The sensory characteristics of the samples were determined by a panel consisting of five members with proven tasting abilities. The panelists passed 
the triangular test for differentiation of fresh and rancid sausage flavour, odor, and colour [Grobbel et al. 2008]. The samples were scored using 1 to 5 scales.

The sensory characteristics of the raw marinated meat were carried out as easily as possible after removing from marinade solutions. After cooling at room temperature the packages with cooked meat samples were opened and tested immediately.

Five repetitions $(n=5)$ for each sample were carried out. Data were processed by the analysis of variance (one-way ANOVA) method with a level of significance of $p<0.05$ [Kenward 1987]. Duncan's multiple comparison test (SPSS) with a significant difference set at $p \geq 0.05$ was used to compare sample means. Mean values and standard deviations were reported. The differences between means less than 0.05 were considered statistically significant [Kenward 1987].

\section{RESULTS AND DISCUSSION}

After $24 \mathrm{~h}$ and $48 \mathrm{~h}$ of marinating the best appearance was awarded to the raw and roasted alkaline marinated samples (AL24 and AL48), followed by acidic marinated samples AC24 and AC 48.

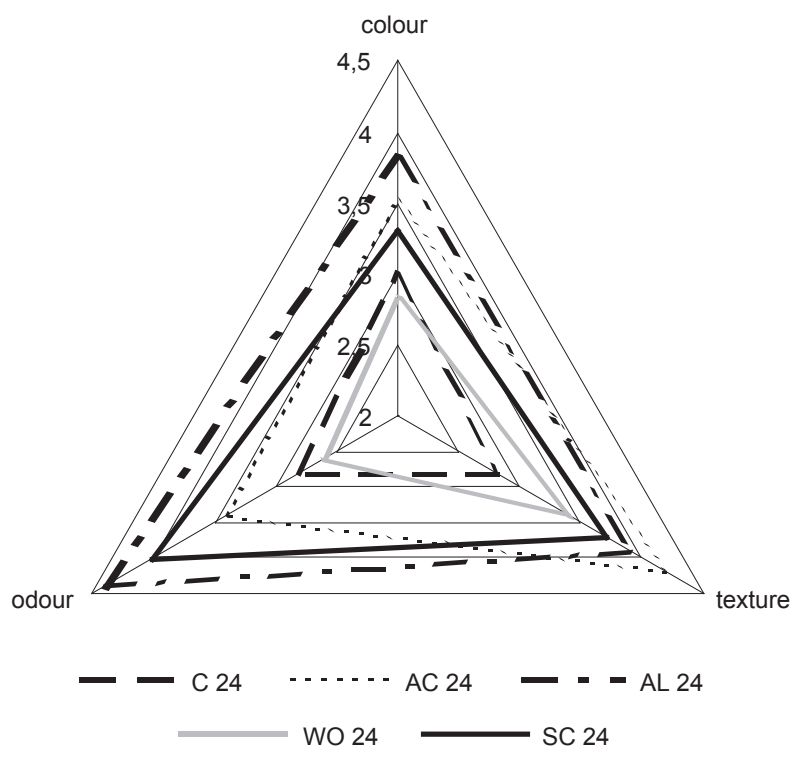

Fig. 1. Sensory assessments of raw horse m. Longissimus dorsi after $24 \mathrm{~h}$ marinating
Throughout the studied period of time ( $48 \mathrm{~h}$ ) the tasting panel found that the least attractive was the colour of raw samples WO24 and WO48 (marinated in water-oil emulsion) (Fig. 1-2). These samples were characterised by darker brown colour with grey hue after $48 \mathrm{~h}$ marinating. During the water-oil marinating, with increase of the marinating time, the negative changes in sensory characteristics of meat samples occur.

A similar trend with development of unusual lighter colour and clearly visible muscle swelling was found after $48 \mathrm{~h}$ marinating of raw samples SC24 and SC48. Water-oil marinated samples (WO24 and WO48) were evaluated with the lowest odor before roasting (Fig. 1-2) and the lowest taste after roasting (Fig. 3-4). According to the tasting panel in water-oil marinated horse meat (samples WO24 and WO48) a negative rancid odor and taste was found (Fig. 1-4).

The overall sensory scores was influenced statistically significant $(\mathrm{p} \leq 0.05)$ by marinating time only in the raw water-oil marinated (WO24 and WO48) samples (Table 1), and in the alkaline marinated (AL24 and AL48) samples $(\mathrm{p} \leq 0.05)$ after roasting (Table 2$)$.

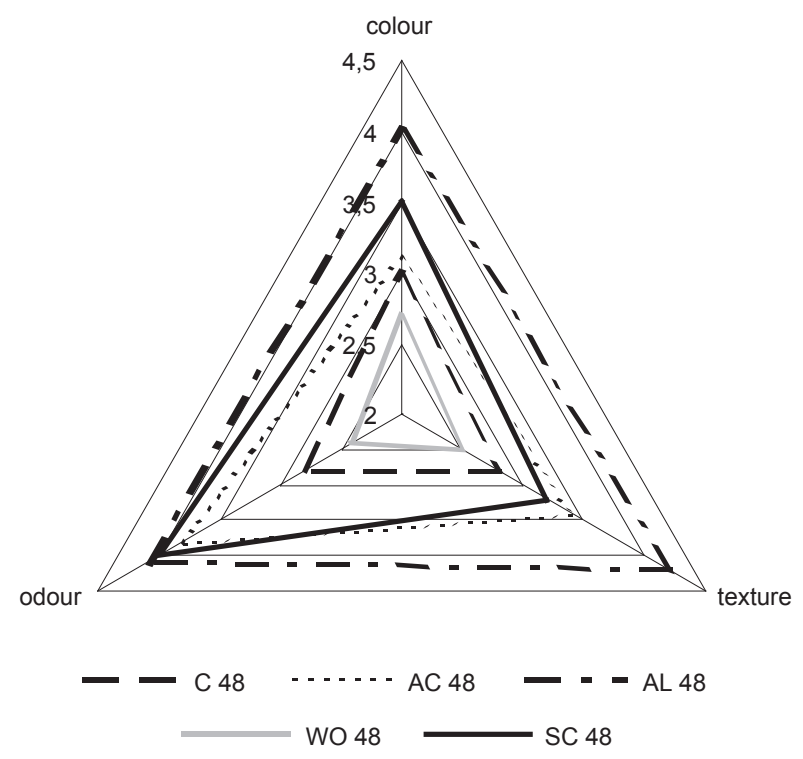

Fig. 2. Sensory assessments of raw horse m. Longissimus dorsi after $48 \mathrm{~h}$ marinating 
Vlahova-Vangelova D.B., Abjanova S., Dragoev S.G., 2014. Influence of the marinating type on the morphological and sensory properties of horse meat. Acta Sci. Pol., Technol. Aliment. 13(4), 403-411.

Table 1. Overall sensory scores of marinated horse meat before roasting

\begin{tabular}{ccc}
\hline Sample & $24 \mathrm{~h}$ & $48 \mathrm{~h}$ \\
\hline C & $11.6^{\mathrm{a}, \mathrm{x}} \pm 0,84$ & $11.6^{\mathrm{a}, \mathrm{x}} \pm 0.85$ \\
AL & $16.4^{\mathrm{c}, \mathrm{x}} \pm 0.42$ & $15.7^{\mathrm{c}, \mathrm{x}} \pm 0.84$ \\
AC & $14.5^{\mathrm{b}, \mathrm{x}} \pm 0.84$ & $13.7^{\mathrm{b}, \mathrm{x}} \pm 0.61$ \\
WO & $12.0^{\mathrm{a}, \mathrm{x}} \pm 0.41$ & $10.6^{\mathrm{a}, \mathrm{y}} \pm 0.67$ \\
SH & $14.3^{\mathrm{b}, \mathrm{x}} \pm 0.55$ & $13.6^{\mathrm{b}, \mathrm{x}} \pm 0.45$
\end{tabular}

Mean \pm SD.

a,b,c Index showing data with statistical different value in columns $(\mathrm{p}<0.05)$.

${ }^{x, y}$ Index showing data with statistical different value in rows $(\mathrm{p}<0.05)$

For all other samples the overall sensory scores was not affected by marinating time (Table 1 and 2 ).

The highest sensory scores before roasting were awarded to samples AL24 and AL48 (Table 1). The most attractive bright red colour of the raw horse meat was found after $24 \mathrm{~h}$ alkaline marinating (sample MA24; Fig. 1 and 2), an indicator which is of primary

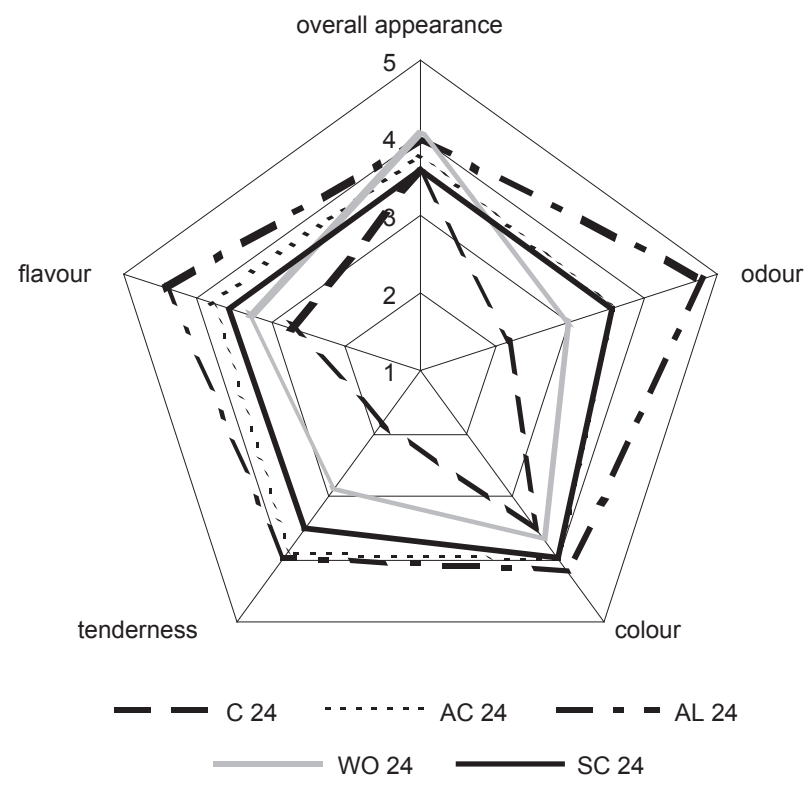

Fig. 3. Sensory assessments of cooked horse $m$. Longissimus dorsi after $24 \mathrm{~h}$ marinating
Table 2. Overall sensory scores of marinated horse meat after roasting

\begin{tabular}{ccc}
\hline Sample & $24 \mathrm{~h}$ & $48 \mathrm{~h}$ \\
\hline C & $14.4^{\mathrm{a}, \mathrm{x}} \pm 0.98$ & $14.4^{\mathrm{a}, \mathrm{x}} \pm 0.98$ \\
AL & $21.4^{\mathrm{d}, \mathrm{x}} \pm 0.89$ & $23.1^{\mathrm{d}, \mathrm{y}} \pm 0.67$ \\
AC & $19.1^{\mathrm{c}, \mathrm{x}} \pm 0.74$ & $19.0^{\mathrm{c}, \mathrm{x}} \pm 0.54$ \\
WO & $16.9^{\mathrm{b}, \mathrm{x}} \pm 0.74$ & $16.2^{\mathrm{b}, \mathrm{x}} \pm 0.65$ \\
SH & $18.3^{\mathrm{c}, \mathrm{x}} \pm 0.54$ & $18.8^{\mathrm{c}, \mathrm{x}} \pm 0.67$ \\
\hline
\end{tabular}

Mean \pm SD.

$\mathrm{a}, \mathrm{b}, \mathrm{c}$ Index showing data with statistical different value in columns $(\mathrm{p}<0.05)$

${ }^{x, y}$ Index showing data with statistical different value in rows $(\mathrm{p}<0.05)$.

importance for consumer demand. After roasting, the tenderness of the alkaline marinated horse meat (AL48 and AL24) had the highest sensory scores, followed by the acid marinated samples (AC48 and AC24; Fig. 3 and 4).

Irrespective of the fact that alkaline marinated meat for $48 \mathrm{~h}$ was awarded with highest overall sensory

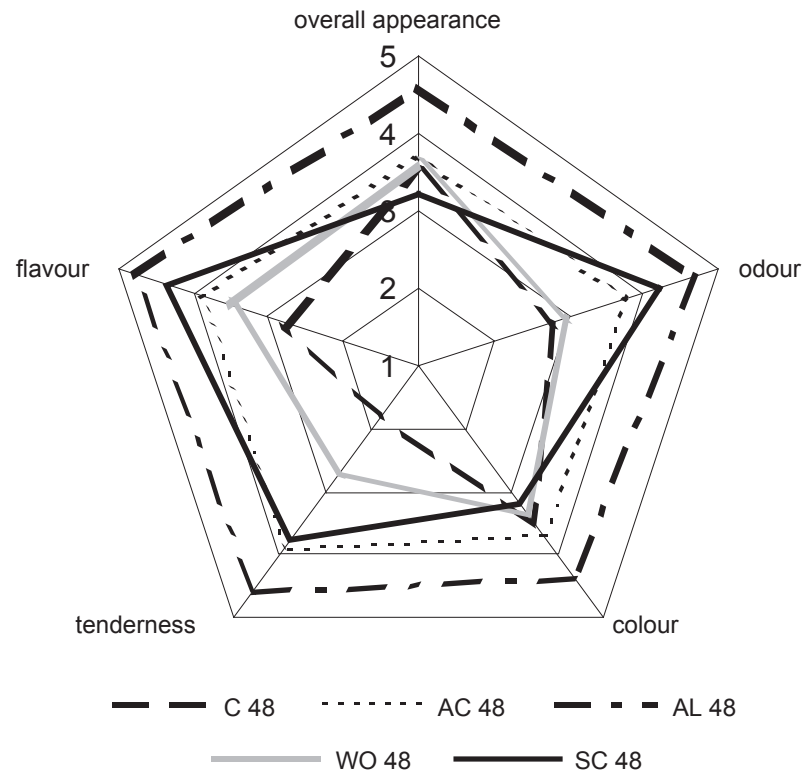

Fig. 4. Sensory assessments of cooked horse m. Longissimus dorsi after $48 \mathrm{~h}$ marinating 
Vlahova-Vangelova D.B., Abjanova S., Dragoev S.G., 2014. Influence of the marinating type on the morphological and sensory properties of horse meat. Acta Sci. Pol., Technol. Aliment. 13(4), 403-411.

Table 3. $\mathrm{pH}$ changes in horse meat during marinating

\begin{tabular}{crr}
\hline Sample & \multicolumn{1}{c}{$24 \mathrm{~h}$} & \multicolumn{1}{c}{$48 \mathrm{~h}$} \\
\hline C & $6.0^{\mathrm{a}, \mathrm{x}} \pm 0.04$ & $5.6^{\mathrm{c}, \mathrm{y}} \pm 0.03$ \\
AL & $6.65^{\mathrm{d}, \mathrm{x}} \pm 0.07$ & $7.1^{\mathrm{d}, \mathrm{y}} \pm 0.05$ \\
AC & $6.26^{\mathrm{b}, \mathrm{x}} \pm 0.02$ & $6.67^{\mathrm{b}, \mathrm{y}} \pm 0.03$ \\
WO & $6.6^{\mathrm{d}, \mathrm{x}} \pm 0.05$ & $6.8^{\mathrm{c}, \mathrm{y}} \pm 0.02$ \\
SH & $6.4^{\mathrm{c}, \mathrm{x}} \pm 0.07$ & $7.1^{\mathrm{d}, \mathrm{y}} \pm 0.05$ \\
\hline
\end{tabular}

Mean \pm SD

a,b,c Index showing data with statistical different value in columns $(\mathrm{p}<0.05)$.

$\mathrm{x}, \mathrm{y}$ Index showing data with statistical different value in rows $(\mathrm{p}<0.05)$.

scores before and after roasting (Table 1 and Table 2), the tasting panel found unusually smooth and shiny surface in samples AL48.

A probable cause for the observed phenomenon was maceration caused by activation of proteolytic enzymes [Pazos et al. 2002], due to the shift of pH in their optimal activity (Table 3 ). Another possible cause was the lower initial $\mathrm{pH}$ of horse meat (Table 3), leading to stronger effect of the alkaline marinade solutions. The highest autolytic changes after 48 $\mathrm{h}$ alkaline marinating with $2 \%$ phosphates and $2 \%$ sodium chloride solutions in horse $m$. Longissimus dorsi were found (Fig. 9 and 10) in comparison with the other types of marinating. After roasting, the tasting panel calcified the samples (Table 2) as follows AL48 $>\mathrm{AL} 24>\mathrm{AC} 24>\mathrm{AC} 48>\mathrm{SC} 48>\mathrm{SC} 24>\mathrm{WO} 24>$ $\mathrm{WO} 48>\mathrm{C}$.

After roasting, the marinating time $(24 \mathrm{~h}$ or $48 \mathrm{~h})$ statistically significantly influenced only the alkaline marinated samples $(p \leq 0.05)$. For all other roasted samples a statistically significant difference during the time ( $24 \mathrm{~h}$ or $48 \mathrm{~h}$ ) was not found.

The observation of muscle tissue in the microscopic pictures (Fig. 5-14) confirmed the results found at sensory analysis of the horse meat.

Compared to the control samples (Fig. 5-8) it was ascertained that alkaline marinating causes highest proteolytic and morphological changes in the muscle and connective tissues (Fig. 9-10), followed by acid marinating (Fig. 11-12). The morphological observation showed that water-oil marinating causes

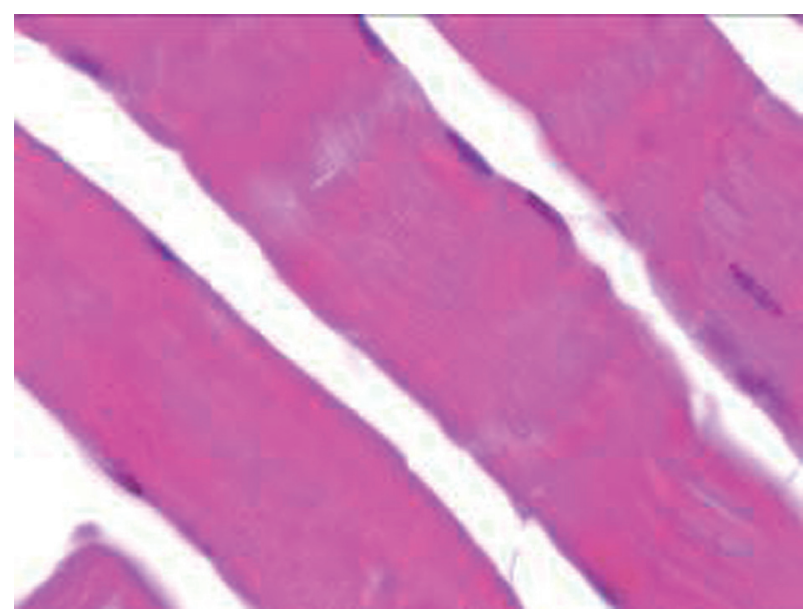

Fig. 5. Control sample, longitudinal section (LS) of horse m. Longissimus dorsi (24 h post mortem), hematoxylin stained, $1000 \mathrm{x}$

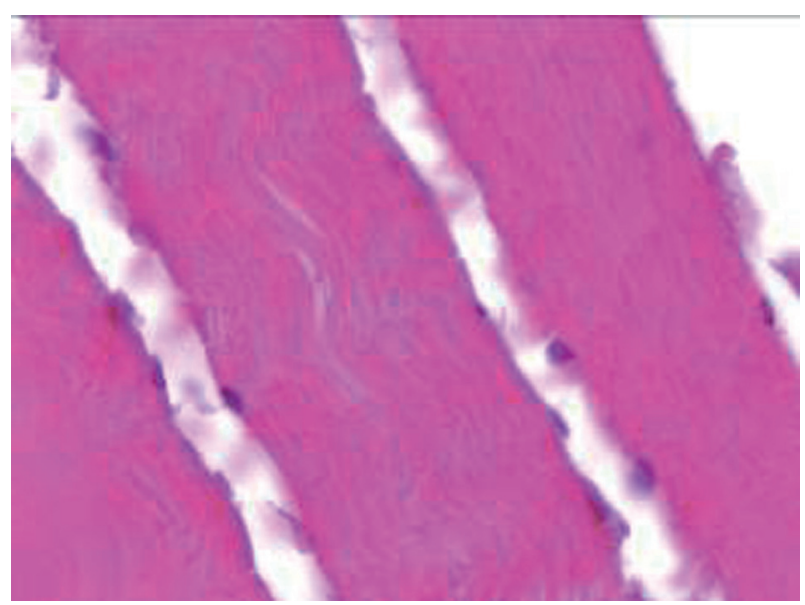

Fig. 6. Control sample, longitudinal section (LS) of horse m. Longissimus dorsi (3 d post mortem), hematoxylin stained, $1000 \mathrm{x}$

the slightest changes in the muscle and connective tissues of horse meat (Fig. 13-14).

In comparison to control samples C (Fig. 5-8), the ingredients of the marinade solution caused opening of the protein chains, loosening of the myofibrillar structure [Sultana et al. 2008] and increase in the amount of water held in muscles [Sheard and Tali 2004] (Fig. 9-14). 


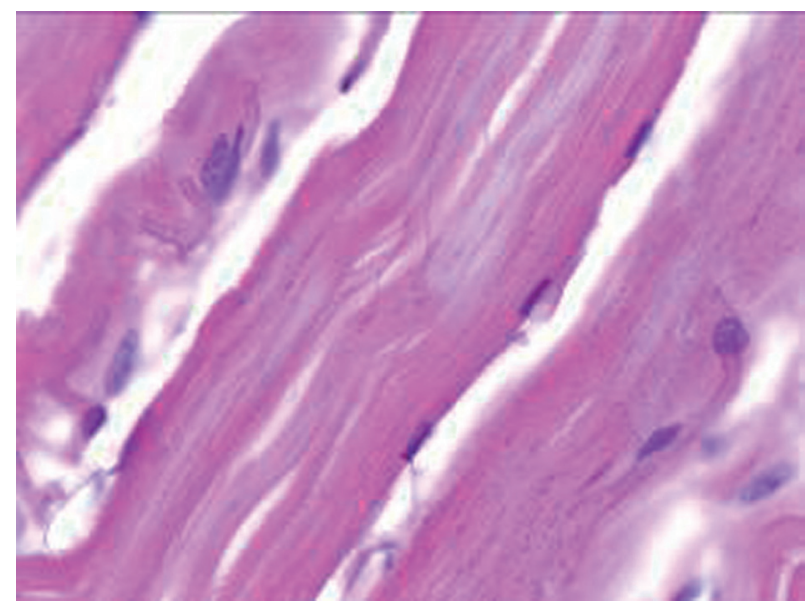

Fig. 7. Control sample, longitudinal section (LS) of horse m. Longissimus dorsi (7 d post mortem), hematoxylin stained, $1000 \mathrm{x}$

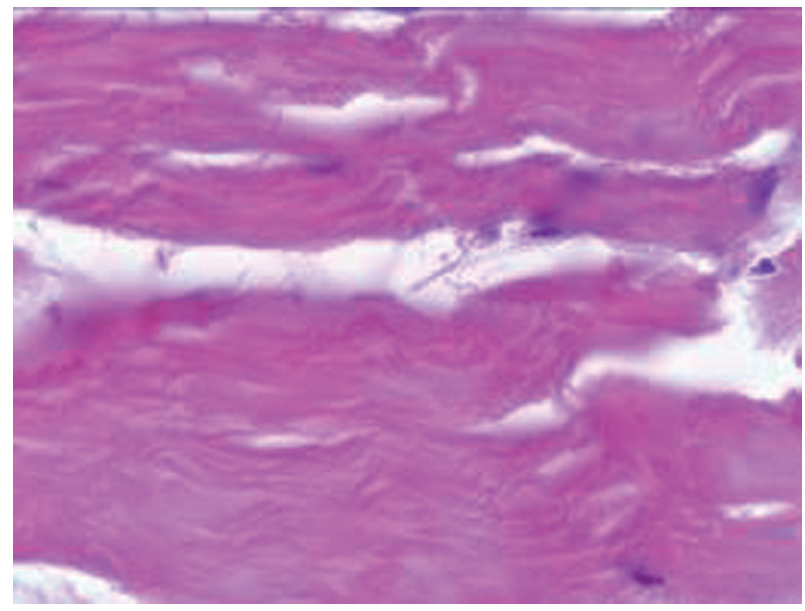

Fig. 8. Control sample, longitudinal section (LS) of horse m. Longissimus dorsi (9 d post mortem), hematoxylin stained, $1000 \mathrm{x}$

The swelling in muscle fibers was greater after $24 \mathrm{~h}$ alkaline marinating (Fig. 9) and occurred in smaller extent in $24 \mathrm{~h}$ acid marinated horse meat (Fig. 11).

Compared to sample AC48 (Fig. 12) muscle fibers in alkaline marinated meat AL48 (Fig. 10) was damaged in the largest extent. Morphological observation of control (Fig. 5-8) and marinated samples was established that changes in muscle fibers after $24 \mathrm{~h}$ acid

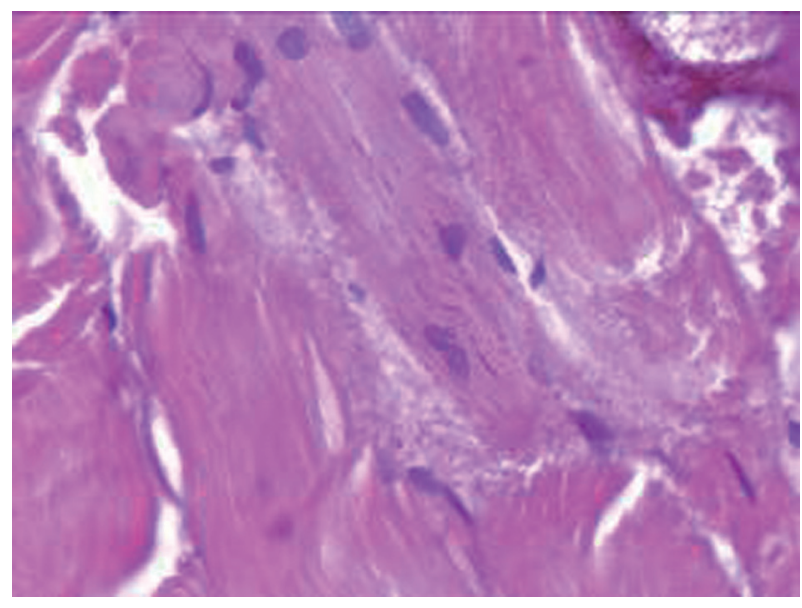

Fig. 9. Sample AL24, longitudinal section (LS) of horse m. Longissimus dorsi, hematoxylin stained, 1000x

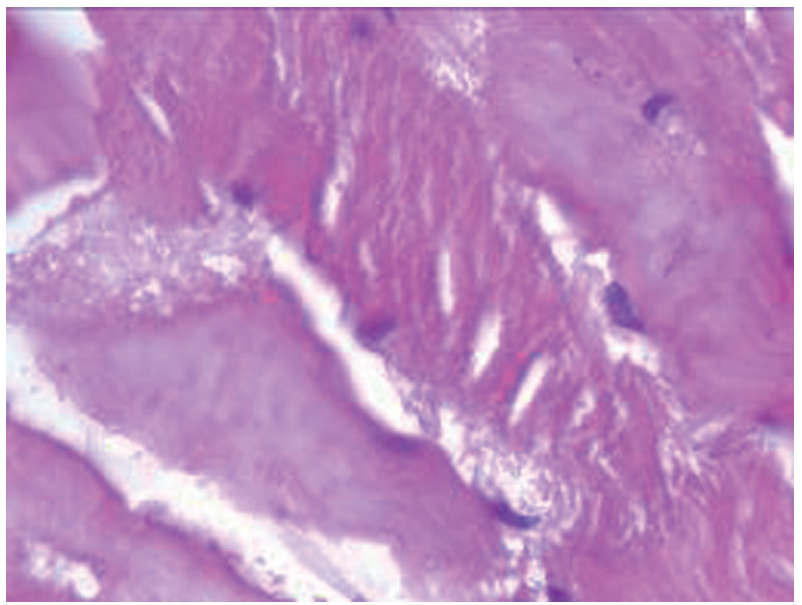

Fig. 10. Sample AL48, longitudinal section (LS) of horse m. Longissimus dorsi, hematoxylin stained, 1000x

(Fig. 11) and alkaline (Fig. 9) marinating, was similar to changes in control sample after 9 days of storage at $0-4^{\circ} \mathrm{C}$ (Fig. 8).

The greatest swelling was found after $24 \mathrm{~h}$ soaking in $2 \% \mathrm{NaCl}$ solution (Fig. 15-16) leading to unusual appearance of samples SC24 and SC48.

Except changes in muscle tissue, marinade ingredients influence on connective tissue native structure. 


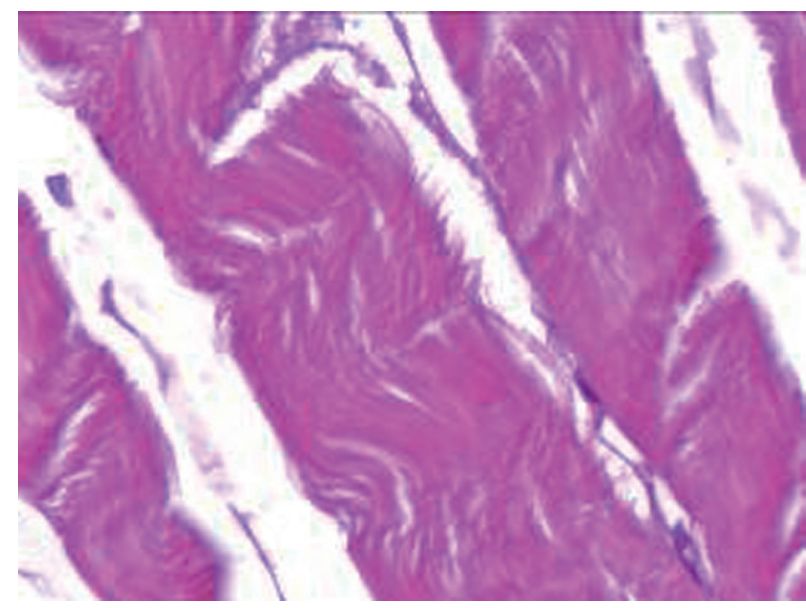

Fig. 11. Sample AC24, longitudinal section (LS) of horse m. Longissimus dorsi, hematoxylin stained, 1000x

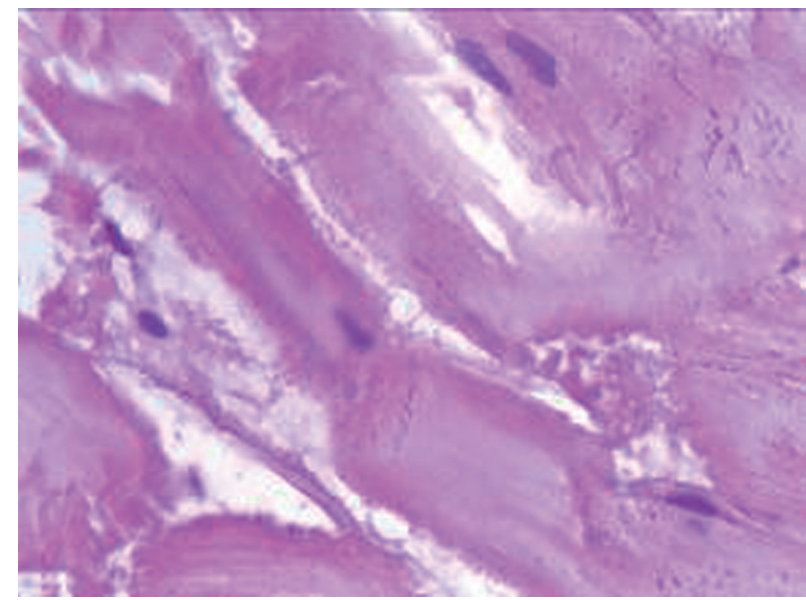

Fig. 12. Sample AC48, longitudinal section (LS) of horse m. Longissimus dorsi, hematoxylin stained, 1000x

These changes were confirmed with the data on the indicator 'tenderness' of the roasted products (Fig. 3-4). One possible reason for changes in native structure of connective tissue is the action of activated proteases and another one is mechanical impact on the connective tissue endomysium caused by muscle tissue swelling [Sultana et al. 2008].

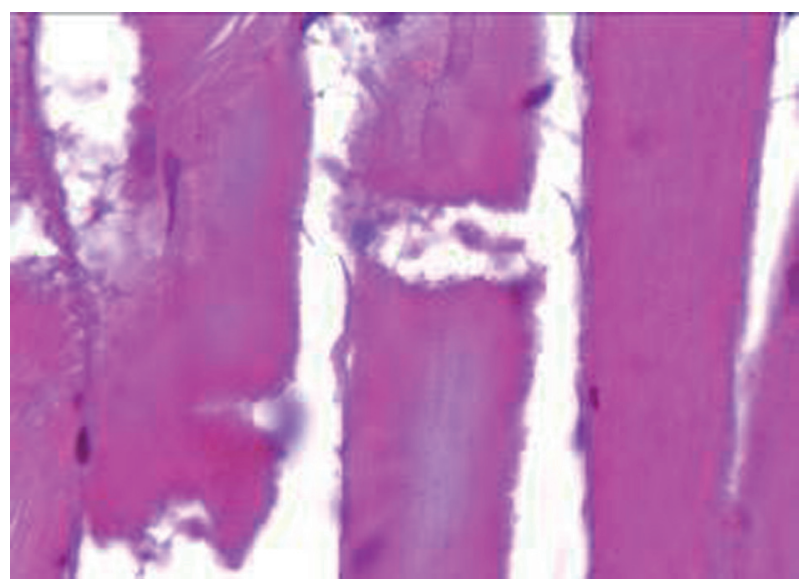

Fig. 13. Sample WO 24, longitudinal section (LS) of horse m. Longissimus dorsi, hematoxylin stained, 1000x

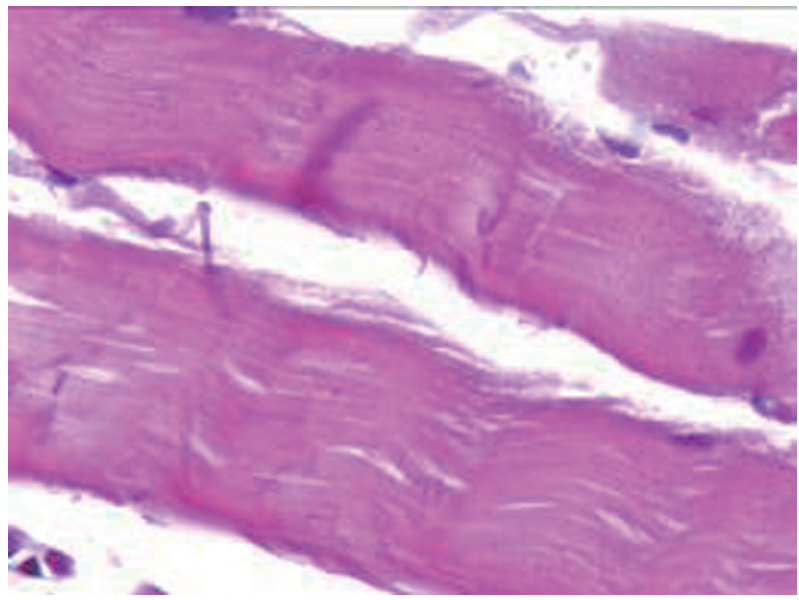

Fig. 14. Sample WO48, longitudinal section (LS) of horse m. Longissimus dorsi, hematoxylin stained, 1000x

\section{CONCLUSION}

The results and their analysis allow us to conclude that in comparison to the acid and water-oil marinating, alkaline marinating improve the sensory properties (colour, odor, taste and tenderness) of horse meat in greatest extent. The highest swelling of the muscle tissue, accompanied by an increase in the water held in 


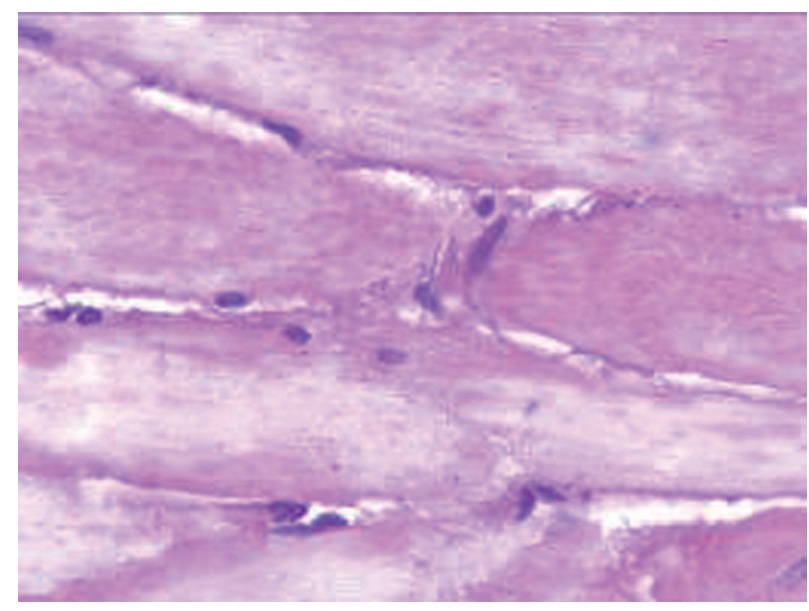

Fig. 15. Sample SC24, longitudinal section (LS) of horse m. Longissimus dorsi, hematoxylin stained, $1000 \mathrm{x}$

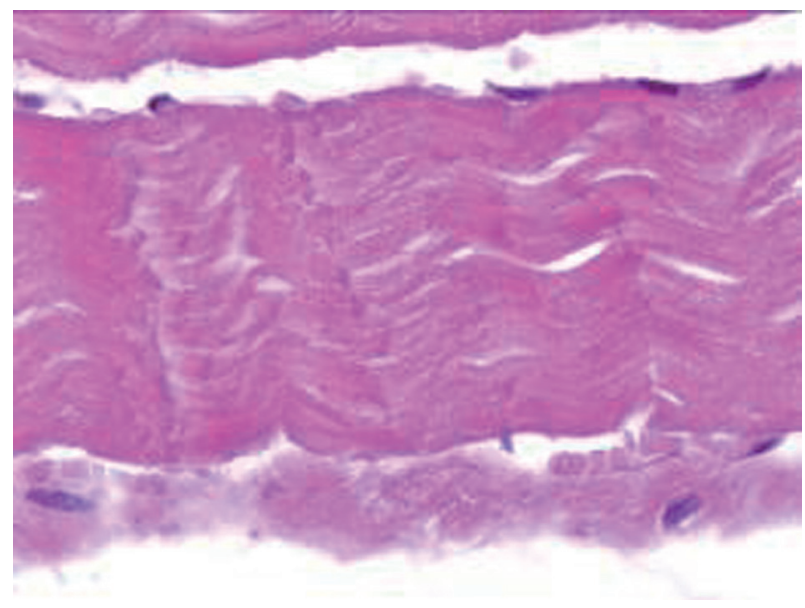

Fig. 16. Sample SC48, longitudinal section (LS) of horse $m$. Longissimus dorsi, hematoxylin stained, 1000x

muscles caused the most pronounced tenderization in alkaline marinated horse meat. Changes in connective tissue and muscle tissue increased as follows: AL48 $<$ AL24 $<$ AC48 = AC24, but this type of marinating should be conducted for $24 \mathrm{~h}$ because after $48 \mathrm{~h}$ marinating a soft and unusually tender texture in alkaline marinated meat occurs. These changes were confirmed with morphological observation of samples AL48 and AC48 showed that the muscle tissue and connective tissue was disrupted to the largest extent. After $24 \mathrm{~h}$ marinating with $2 \% \mathrm{SL}$ and $2 \% \mathrm{NaCl}$ or $2 \%$ polyphosphates and $2 \% \mathrm{NaCl}$ changes in muscle tissue are similar to changes in control samples after $9 \mathrm{~d}$ storage at $0-4^{\circ} \mathrm{C}$.

\section{ACKNOWLEDGEMENT}

The authors are pleased to acknowledge the Almaty Technological University, Almaty, Kazakhstan for support.

\section{REFERENCES}

Alvarado C., McKee S., 2007. Marination to improve functional properties and safety of poultry mteat. J. Appl. Poult. Res. 16, 113-120.

Barbut S., 2002. Poultry products - formulation and gelation. Poultry products processing. In: An industry guide. CRC Press New York, 249-288.

Brooks J.C., 2005. Tender is the bite. Meat Market. Techn. 13, 10, 101-104.

Björkroth K.J., 2005. Microbial ecology of marinated meat products. Meat Sci. 70, 477-480.

Ergezer H., Gokce R., 2011. Comparison of marinating with two different types of marinade on some quality and sensory characteristics of Turkey breast meat. J. Anim. Vet. Adv. 10, 1, 60-67.

Grobbel J.P., Dikeman M.E., Hunt M.C., Milliken G.A., 2008. Effects of different packaging atmospheres and injection-enhancement on beef tenderness, sensory attributes, desmin degradation, and display color. J. Anim. Sci. 86 (10), 2697-2710.

Hinkle J.B., 2010. Acid marination for tenderness enhancement of beef bottom round. Theses and Dissertations in Animal Science. Paper 12. University of Nebraska Lincoln. European Food Research and Technology.

Kenward M.G., 1987. A method for comparing profiles of repeated measurements. Appl. Statist. 36, 296-308 [online], http://www.jstor.org/discover/10.2307/234788?ui $\mathrm{d}=2129$ \&uid=2\&uid=70\&uid=4\&sid=2110261664990.

Latif S., 2011. Effect of marination on the quality characteristics and microstructure of chicken breast meat cooked by different methods. Lucrări Stiinţifice 54, Seria Zootehnie, 314-324.

Offer G., Knight J., 1983. On the mechanism of water holding in meat: the swelling and shrinking of myofibrils. Meat Sci. 8, 245-281.

Pearson A.M., Young R.B., 1989. Some condition occurring in muscle/meat. In: Muscle and meat biochemistry. Acad. Press New York, 420-439. 
Vlahova-Vangelova D.B., Abjanova S., Dragoev S.G., 2014. Influence of the marinating type on the morphological and sensory properties of horse meat. Acta Sci. Pol., Technol. Aliment. 13(4), 403-411.

Pazos A.A., Salitto V.A., Lasta J.A., Bolondi A., Guidi S.M., Carduza F.J., Gonzalez C.B., 2002. Tenderness improvement of bovine biceps femoris muscle by calcium chloride injection. J. Musc. Foods 13, 171-187, doi: 10.1111/j.1745-4573.2002.tb00329.

Sheard P.R., Tali A., 2004. Injection of salt, tripolyphosphate and bicarbonate marinade solutions to improve

Received - Przyjęto: 28.04.2014

For citation - Do cytowania the yield and tenderness of cooked pork loin. Meat Sci. $68,305-311$.

Sultana A., Nakanishi A., Roy B.C., Mizunoya W., Tatsumi R., Ito T., Tabata S., Rashid H., Katayama S., Ikeuchi Y., 2008. Quality improvement of frozen and chilled beef biceps femoris with the application of salt-bicarbonate solution. Asian-Aust. J. Anim. Sci. 21, 903-911.

Accepted for print - Zaakceptowano do druku: 11.08.2014

Vlahova-Vangelova D.B., Abjanova S., Dragoev S.G., 2014. Influence of the marinating type on the morphological and sensory properties of horse meat. Acta Sci. Pol., Technol. Aliment. 13(4), 403-411. 